Portland State University

PDXScholar

\title{
The Oregon Coastal Worry: Cellular Division Affected by External Changing Temperatures and Salinity Concentration
}

Jessica Sheets

Portland State University

Follow this and additional works at: https://pdxscholar.library.pdx.edu/honorstheses

Let us know how access to this document benefits you.

Recommended Citation

Sheets, Jessica, "The Oregon Coastal Worry: Cellular Division Affected by External Changing Temperatures and Salinity Concentration" (2019). University Honors Theses. Paper 729. https://doi.org/10.15760/honors.747

This Thesis is brought to you for free and open access. It has been accepted for inclusion in University Honors Theses by an authorized administrator of PDXScholar. Please contact us if we can make this document more accessible: pdxscholar@pdx.edu. 


\title{
The Oregon Coastal Worry: Cellular Division Affected by External Changing Temperatures and Salinity Concentration
}

\author{
By \\ Jessica Sheets \\ An undergraduate honors thesis submitted in partial fulfillment of the \\ requirements for the degree of \\ Bachelor of Science \\ In \\ University Honors \\ And \\ Biology \\ Thesis Advisor: \\ Bradley Buckley
}

Portland State University

Spring 2019 


\title{
THE OREGON COASTAL WORRY: CELLULAR DIVISION AFFECTED BY EXTERNAL CHANGING TEMPERATURES AND SALINITY CONCENTRATION
}

Jessica Sheets

Portland State University

14 June 2019

\begin{abstract}
Marine life is highly susceptible to stress and physiological impact through climate change, as this directly alters thermal temperatures and salinity concentrations of the ocean. The coastal species, Mytilus edulis, a mussel found variously in the northern hemisphere, was selected for cellular stress response testing. Through the investigation of temperature and salinity effects on Mytilus edulis using separation group exposure and flow cytometry analysis, it was found that salinity changes had significantly impacted the cellular division process. Individuals who received the environmentally controlled salinity concentration of 32ppt had abundant cells staged in the $S$ phase of cellular division. Mussels exposed to salinity concentrations of 16ppt had reduced cells in the S phase, with the highest peak shifted to the left, indicative of increased cells in $G_{0} / G_{1}$ phase. In comparing the groups exposed to $13^{\circ} \mathrm{C}$ versus $21^{\circ} \mathrm{C}$, similar results were seen, with the higher temperature being the advantaged group. Future testing using several varying temperatures between ranges of $5^{\circ} \mathrm{C}$ to $30^{\circ} \mathrm{C}$ may provide more information on how ocean warming can directly impact cellular response of Mytilus edulis.
\end{abstract}

Key Words: Oregon coast, Blue Mussel, Mytilus edulis L., thermal regulation, cellular division, Ocean warming, climate change, Flow Cytometry, salinity

\section{INTRODUCTION}

As the world continues to warm and causing ice caps to melt, several species are put at risk of endangerment, and eventually extinction. It has been publicly debated for years whether our earth faces an environmental catastrophe known as global warming, where our earth's atmosphere increases in temperature due to greenhouse gas build up. The world's ocean surfaces have warmed $0.7 \circ \mathrm{C}\left(33.26^{\circ} \mathrm{F}\right)$ within the last 100 years (Gruber 2011). Although this change appears minuscule and insignificant, any measure of ocean warming can be detrimental 
to marine ecosystems, as most marine processes are temperature dependent (Gruber 2011). Organisms' bodies are constantly responding to their environments, which includes changes of temperature, $\mathrm{pH}$ levels, and salinity. For humans, precipitate drips down our faces on a hot day to cool the body on a cold day, our muscles readily contract and expand rapidly to warm the body. Both sweating and shivering are coordinated physiological responses that correlate to a natural animal phenomenon known as homeostasis. Homeostasis is the ability for organisms to maintain internal equilibrium relative to external factors that may affect internal conditions. Within humans, homeostasis is regulated by a region of the brain called the hypothalamus (Hill 2008). The hypothalamus is like a thermostat when our homes get cold; it receives information from the sensor when the environment temperature has changed and sends a message to the rest of the body on how to response to said changes to maintain internal equilibrium.

The hypothalamus can be found in most mammal brains, however, mussels and hundreds of other marine species lack this adaptation. Instead, much of sea creatures are ectotherms poikilotherms: animals whose temperature changes depending on the environmental temperature (Shmoop Editorial Team 2008). Therefore, in the case of mussels, their internal body temperature is greatly dependent on water temperature. Mobile marine species such as fish will often alter their behavior in response to temperature changes, such as diving deeper into water when the water becomes too warm up top. However, mussels are limited to a few behavioral modifications in order to adjust to changing environmental temperatures, seeing that they are unable to mobility displace themselves. Each species has an optimal temperature preference and temperatures outside of that scope can have a profound influence on oxygen consumption (Axelsson). Temperature is considered the "ecological master factor" and affects the entire life cycle of marine species (Brent, 1970).

Since mussels are so impacted by water temperature, water temperature variations can cause mussels to go into stress. Naturally, a "cell's initial response to a stressful stimulus is geared towards helping the cell to defend against and recover from the insult. However, if the noxious stimulus is unresolved, then cells activate death signaling pathways" (Fulda, 2010). When an organism is under stress, their cells will not readily replicate, and instead, go into apotosis. For cells to make an identical copy of themselves, they must go through four important steps: $G_{1}$ phase (checkpoint and cell grows), $S$ phase (DNA is replicated), $G_{2}$ phase (checkpoint and cell grows more), and mitosis (cell division). Cells experiencing stress are likely to get stuck in either the $\mathrm{G}$ checkpoints (especially $\mathrm{G}_{1}$ ), since the cell will not split if the environment isn't well suited for survival. With inhibited cell replication, the organism would eventually die, since 
hundreds of cells need to be replaced daily, whether to replace damaged cells or help an organism grow (Dr. Biology, 2014).

Marine species play a vital role in maintaining life. They are a main food supply for hundreds of species and are predators for insects, plants, and smaller marine species. Without mussels, several ecosystems would collapse since many predators would lack a primary source of food. This would deeply impact humans too, since $16 \%$ of our consumed protein comes from seafood (Tidwell, 2001). With ocean warming on the rise, it is necessary to identify temperatures that set fish into physiological stress. This leads me to the question of focus on for the thesis project: Which oceanic temperatures trigger Oregon blue mussels' stress response, thereby preventing cellular division and species growth? Can alteration of salinity concentration increase this impact?

\section{Mytilus edulis:}

Mytilus edulis, or better known as the blue mussel, is a shellfish that resides along the coastal areas (usually 5 to 10 meters of depth) of prominently North America, Europe, and Asia. Once in the adult stage, they will permanently attach themselves to a rocky shore bed where they will continue to live out their life, despite environmental conditions (Zagata 2008). This mollusk are eurythermal and ectothermic species, meaning their core body temperature is strictly dependent on their environment and behavioral adaptations (no internal homeostasis regulation mechanism) but have a wide range of temperature tolerance. They are considered quite "hardy," seeing that they are capable of withstanding large changes to their environment. This includes daily fluctuations of temperature (well adapted to changing water temperatures of $5^{\circ} \mathrm{C}$ to $20^{\circ} \mathrm{C}$ with a maximal temperature of $29^{\circ} \mathrm{C}$ before sustainability deterioration) and salinity (minimal salinity concentration needed for population survival is $15 \%$ saltwater) (Zagata 2008).

Although direct evidence indicates the blue mussels' have a natural ability to acclimate for changing environmental conditions, this does not deter from stress that their bodies/cells likely undergo constantly. All animals have a range of thermal and salinity tolerance, whether it be a narrow or wide one, but within that range, there exist the most optimal conditions that cause little to no stress on the organism. Perhaps Mytilus edulis can survive within a range of $5^{\circ} \mathrm{C}$ to $20^{\circ} \mathrm{C}$, but their cells can show signs of slowed replication, indicating that the temperature is not an ideal one for continued sustainability. 


\section{METHODOLOGY}

Oregon marine species were chosen to conduct the research since I currently reside here, which allows for easier species gathering. I have selected the Oregon Blue mussel, Mytilus edulis L., to conduct my research on, since this coastal species of mussel undergo constant thermal and salinity changes due to daily tide differences. To determine what temperatures causes Mytilus edulis $L$ to go into stress, A process called flow cytometry will be used.

The blue mussels were obtained from Portland Fish Market, where they had been stored on ice. Storing mussels on ice puts them into a chilled, hibernation like state, without causing any harm. All mussels were checked for life after received and placed into prepared lab tanks. The mussels were arranged into 4 groups, with 10-12 individuals in each, exposed to varying water temperatures and salinity concentrations as follows:

Table 1: Mytilus edulis experimental groups.

\begin{tabular}{|l|l|l|l|}
\hline Tank & Condition & Temperature & Salinity \\
\hline 1 & Control & $13^{\circ} \mathrm{C}$ & $32 \mathrm{ppt}$ \\
\hline 2 & Temperature Variance & $21^{\circ} \mathrm{C}$ & $32 \mathrm{ppt}$ \\
\hline 3 & Salinity Variance & $13^{\circ} \mathrm{C}$ & $16 \mathrm{ppt}$ \\
\hline 4 & Temperature and Salinity Variance & $21^{\circ} \mathrm{C}$ & $16 \mathrm{ppt}$ \\
\hline
\end{tabular}

Temperature $13^{\circ} \mathrm{C}$ represents the average oceanic temperature, so it was selected for as an acting baseline or control in comparing the other groups. Temperature $21^{\circ} \mathrm{C}$ was selected as another temperature used for observation, not only because it mimics standard "room temperature," but because it also sits just outside the upper threshold for "ideal" oceanic temperature range. Mussels were incubated for 1 hour, as indicated by Rachel Palmer's research, an hour is an enough time to indicate whether the environment causes the cells to go into stress. After the subjection period ended, five individuals were randomly selected from each group and were humanly euthanized. Cell samples were collected from the gills (ideal since gills have direct exposure to the water environment) of each mussel, stirred through a mesh top, and stored in sample tubes filled with ethanol for a few days. Following, the samples were centrifuged at $1600 \mathrm{rmp}$ and excess ethanol was removed from the sample pellets. Next, 
PI Stain ${ }^{1}$ was added to each sample in the dark to enable fluorescent labeling. ${ }^{2}$ Each pellet was agitated, vortexed, and transferred to $12 \times 75 \mathrm{~mm}$ test tubes through a mesh top. ${ }^{3}$ Mesh tops were securely replaced with standard tube tops and placed on ice for transportation to the flow cytometer.

\section{Flow Cytometry:}

A flow cytometer measures and quantifies the amount of DNA within each cell and informs us how many cells have two copies of all their DNA versus a single copy. Cells that have two copies have completed the $S$ phase of the cell cycle and are planning to undergo mitosis for cell replication. Before placing cell samples in the flow cytometer, a back flush was performed on the machine to prevent contamination of any samples and all sample wells were labeled electronically. $1 \mathrm{~mL}$ of deionized water was run through the machine first ${ }^{4}$ followed by all 20 samples. All samples were run at a fluidics medium speed, ungated, with a 10,000-cell count. Peak graphs were generated with an independent variable of FL2A (A being area which measures total fluorescence intensity) and cell count as the measured dependent variable. After data was gathered, with graphs generated, a line of reference was inserted along $10^{4}$ for all graphs for final interpretation.

\footnotetext{
${ }^{1} \mathrm{PI}$ solution is made up of 100uL Propidium lodine stock solution, 900uL of PBS, and 10uL of RNase

2 Propidium lodine is light sensitive and must be handled in dark conditions only

${ }^{3}$ Pipette used to transition cells through mesh top to thoroughly separate individual cells of the sample

${ }^{4}$ The DI water acts as a control tester in addition to flushing out the system
} 
FLOW CYTOMETER GRAPH EXAMPLE

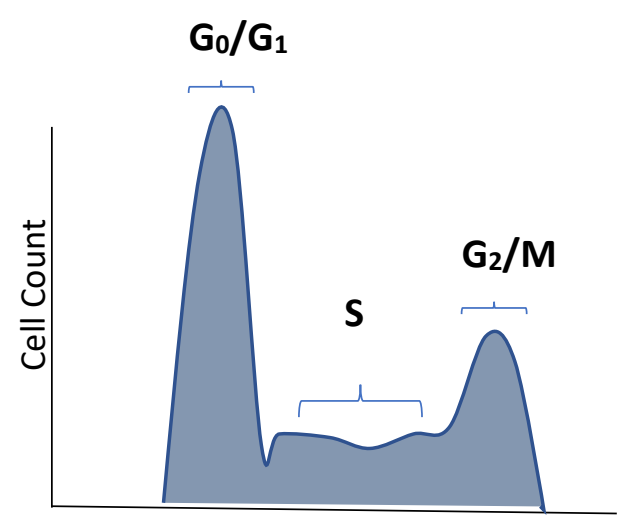

FL2H (Fluorescence Intensity)

Figure 1: Quantitative Flow Cytometer graph for cellular division, more explanation in graph analysis section.

\section{CELLULAR DIVISION CYCLE}

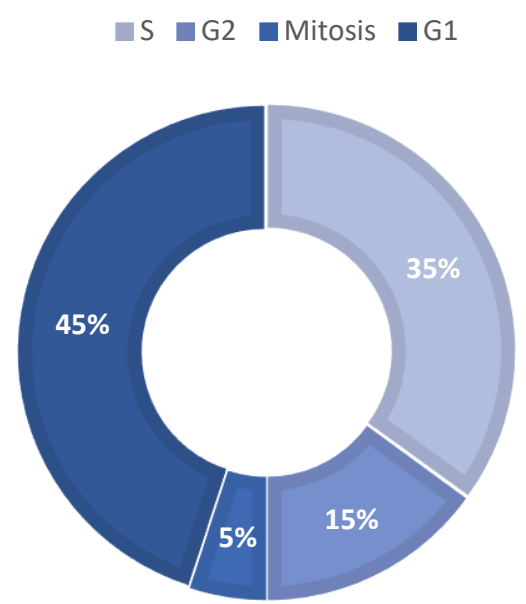

Figure 2: A time percent representative of standard of mammalian cellular division cycle, more explanation in graph analysis section.

\section{Graph Analysis:}

As the cells pass through the laser beam of the flow cytometer, fluorescence of the cells will generate a voltage pulse signal that correlates with a specific FL2A. This is done by a fluorescence detector called the photomultiplier tube (University of Missouri 2019). The first prominent peak on the graph typically corresponds with cells within the $G_{0} / G_{1}$ phase. At this phase, the cells would have less florescence since they have less DNA in comparison to those within or pass the $S$ phase. ${ }^{5}$ The second prominent peak represents cells within $\mathrm{G}_{2}$ or mitosis. Fluorescence is higher for these cells since all these cells possess minimally twice the amount of DNA as seen in $G_{0} / G_{1}$ cells. The more horizontal, transitional part of the graph quantifies the $S$ phase. Unlike the other phases of the cell cycle, the cells undergoing DNA replication can vary heavily in fluorescence. Since the S phase is a process of DNA replication, cells don't simply have 1 or 2 copies of their DNA. Instead, they sit in a range between 1 to 2 full copies (some of the DNA is replicated half the DNA is replicated, most of the DNA is replicated, etc.

\section{RESULTS AND DISSCUSION}

\footnotetext{
${ }^{5}$ Increased DNA causes increased absorption of the dye, resulting in increased fluorescence
} 
The following graphs are of the flow cytometer graph analysis of four groups with FL2-A (Area) versus 10,000 cell count comparison. Data was left ungated due to prominent trend of single peak results. ${ }^{6}$ Graphs also contain title labeling as follows: SC $=32$ ppt salinity and $13^{\circ} \mathrm{C}$ (control); $\mathrm{SH}=32 \mathrm{ppt}$ salinity and $21^{\circ} \mathrm{C} ; \mathrm{FC}=16 \mathrm{ppt}$ salinity and $13^{\circ} \mathrm{C} ; \mathrm{FH}=16 \mathrm{ppt}$ salinity and $21^{\circ} \mathrm{C}$. All graphs had one prominent peak, typically lined along, or closely, with the reference line. More peak shifts to the left, indicative of more cells settled in $\mathrm{G}_{0} / \mathrm{G}_{1}$ versus transitioning into the $S$ phase, can be noted mainly for the Mytilus edulis groups incubated in 16ppt saltwater versus 32ppt groups, with a 6:3 ratio (FC1, FC2, FC4, FC5, FH3, FH5:SC1, SC2, SC5) of shifted peaks, respectively. A 6:2 ( SC1, SC2, SC5, FC1, FC2, FC4, FC5: FH3, FH5) ratio is seen in comparing the $13^{\circ} \mathrm{C}$ versus $21^{\circ} \mathrm{C}$ groups, respectively, indicative of decreased stress for individuals exposed to the warmer temperatures (which may be related to coastal nature of the species.) SH5 is the only individual whose peak was significantly shifted to the right. All groups had a relatively small right trail, representing the $S$ phase, with slight $G_{2} / M$ peaks for $F C 1$ (between $10^{5}$ and $10^{6}$ ) and FH5 (between $10^{4}$ and $10^{5}$ ), most likely due to increased hardiness of the individuals to withstand their environment (better adapted to change.)

It is not understood why the individuals lacked a strong $\mathrm{G}_{2} / \mathrm{M}$ peak. Lacking the second peak strongly indicates the mussels are under physiological stress. Even the control, that mocks standard oceanic conditions, showed this same trend. No direct conclusion can be made about the results, but perhaps this was either due to physical stress the mussels were previously under before collected or lab incubation error that sent them into stress despite standard environmental water conditions given to the control group, and slightly altered conditions for the test group. Some notable setbacks that occurred during this research may underline some of the unforeseen experimental results. The first and second set of mussels collected for experimentation had all undergone mass death by unknown reasons. Mussels, including Mytilus edulis, is considered a hardy species capable of withstanding a wide range of temperature and salinity concentration. Therefore, it came to quite a surprised that the first two sets of mussels, scheduled to be originally acclimated for a week to the conditions used in this experiment, all died. Further investigation of the mussels' origin and previous environmental conditions may reveal some explanations.

\footnotetext{
${ }^{6}$ Gating results useful for peak comparisons among the same graph
} 

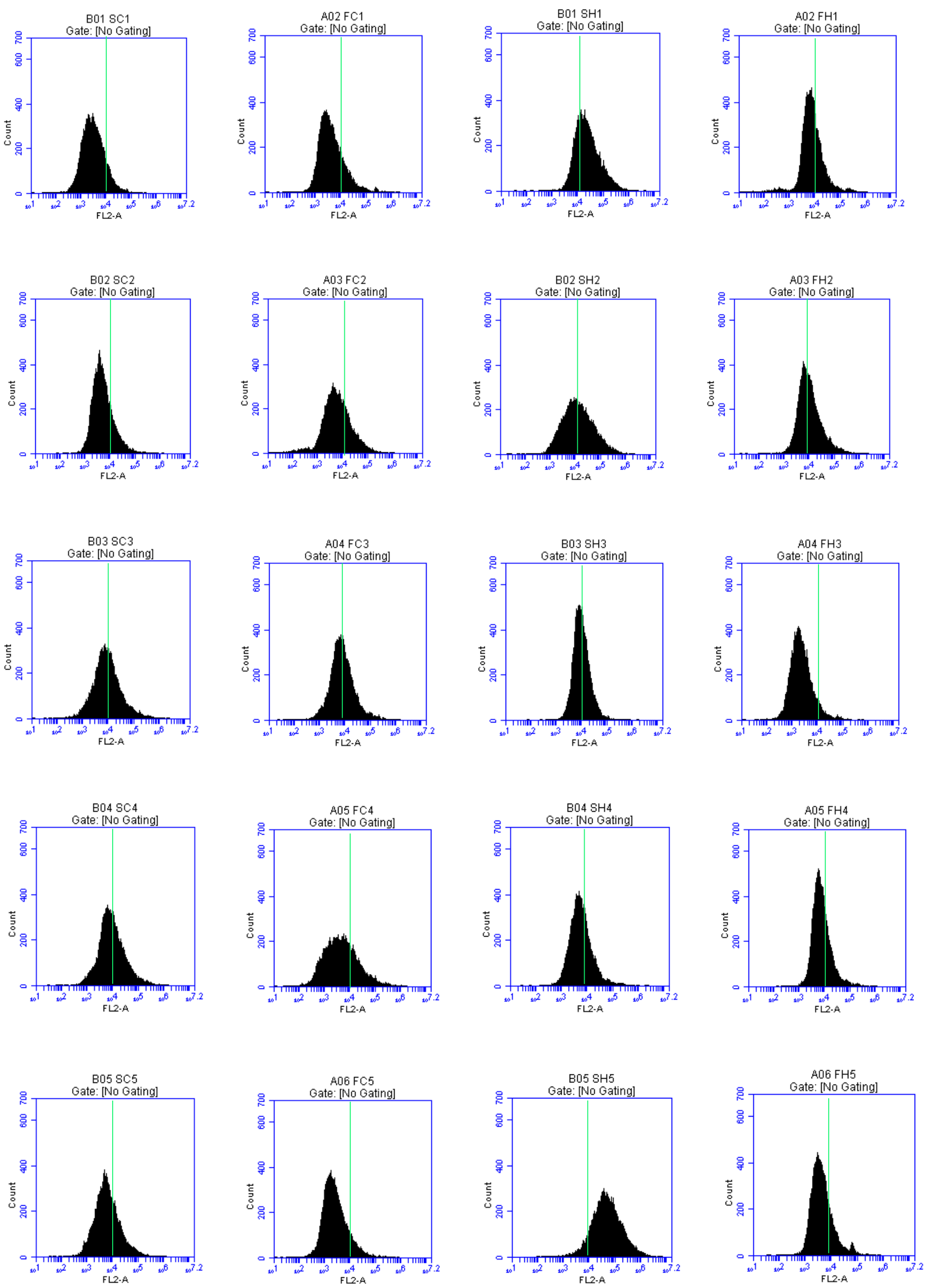

Figure 3: Flow cytometer graph analysis of four groups with FL2-A (Area) versus 10,000 cell count comparison 


\section{CONCLUSION}

In comparing the data among all four groups, it was found that salinity changes had significantly impacted the cellular division process. Individuals who received the environmentally controlled salinity concentration of 32ppt had a shifted cell abundance staged in the $S$ phase of cellular division. Mussels exposed to salinity concentrations of $16 \mathrm{ppt}$ had reduced cells in the $S$ phase, with the highest peak shifted to the left, indicative of increased cells in G0/G1 phase. In comparing the groups exposed to $13^{\circ} \mathrm{C}$ versus $21^{\circ} \mathrm{C}$, similar results were seen. Significance of shifted peaks cannot be made at this time, unfortunately, without statistical analysis. Further research on Mytilus edulis using wider temperature and salinity concentration variances may further expose these key environmental component impacts on cellular stress. In addition, more research on the mussels before any exposure conducted may reveal causes of expected data shifting.

\section{ACKNOWLEDGEMENTS}

I greatly appreciate the help I received from Professor Bradley Buckley for providing his time, lab equipment, and intellectual knowledge to ensure the completeness of this project. I also extend thanks to Janieve Schnabel and David Sauve for their helpful assistance in conducting the mechanical research and Professor Olyssa Starry for writing guidance into creating the final paper and presentation prep.

\section{REFERENCES}

Buckley, Bradley A., and George N. Somero. "CDNA Microarray Analysis Reveals the Capacity of the Cold-Adapted Antarctic Fish Trematomus Bernacchii to Alter Gene Expression in Response to Heat Stress." Polar Biology, 7 Nov. 2008. 32: 403415., doi:10.1007/s00300-008-0533-x.

Fulda, Simone, Adrienne M. Gorman, Osamu Hori, and Afshin Samali, “Cellular Stress Responses: Cell Survival and Cell Death,” International Journal of Cell Biology, vol. 2010, Article ID 214074, 23 pages, 2010.

Gruber, Nicholas. "Warming up, turning sour, losing breath: ocean biogeochemistry under global change." Phil. Trans. R. Soc. A (2011) 369, 1980-1996., doi:10.1098/rsta.2011.0003.

Logan, Cheryl A., and Bradley A. Buckley. "Transcriptomic Responses to Environmental Temperature in Eurythermal and Stenothermal Fishes." The Company of Biologists, 2015. 218: 1915-1924., doi:10.1242/jeb.114397.

Palmer, Rachel. "The Interactive Effect of Temperature and Salinity in the Nile Tilapia (Oreochromis niloticus)." Portland State University, 2018. 
Podrabsky, Jason E., and George N. Somero, "Inducible Heat Tolerance in Antarctic Notothenioid Fishes." Polar Biology, 22 Jun. 2006. 30: 39-43., doi: 10.1007/s00300-006-0157-y

Sanderseld, T., et al. "Elevated Temperature Causes Metabolic Trade-offs at the Whole Organism Level in the Antarctic Fish Trematomuc bernacchii." J Exp Biol., 8 Jun. 2015, doi: 10.1242/jeb.122804.

Sanin, Yasser Lenis, et al. “Adaptive Responses to Thermal Stress in Mammals.” Revuede Medecine Veterinaire, vol. 31, 2015, pp. 121-135.

Sleadd, Isaac M., et al. "Sub-lethal Heat Stress Causes Apoptosis in an Antarctic Fish that Lacks an Inducible Heat Shock Response." Journal of Thermal Biology, August 2014. 44: 119-125., doi: 10.1016/j.jtherbio.2014.06.007

University of Missouri. “Cell Cycle Basics.” Office of Research and Economic Development, 2019.

Zagata, C.; C. Young; J. Sountis and M. Kuehl. "Mytilus edulis." Animal Diversity, 2008. 